\title{
Marketing Strategies Of Small Craft Producers In South Africa: Practices And Challenges
}

\author{
KM Makhitha, University of South Africa (UNISA), South Africa
}

\begin{abstract}
The purpose of this research paper was to investigate the practices and challenges of marketing strategies of craft producers in Gauteng, South Africa (SA). As craft producers lack access to market they are unable to market their products successfully and face major challenges in marketing their products. A survey was conducted among 244 craft producers in Gauteng, South Africa (SA) to determine the marketing strategy practices and the challenges they face when marketing their products. The findings have shown that craft producers introduce new products from time to time and constantly improve existing products. Craft producers believe that their products are unique and of higher quality. They face challenges with the lack of demand for their products and the fact that it is not easy for them to identify customers that want their products. Craft producers need to decide on who they want to target with their products, determine the needs and then formulate an appropriate marketing mix element strategy to reach the chosen target market.
\end{abstract}

Keywords: Marketing Strategy; Craft Producers; Small And Medium Businesses (SMEs); Marketing Mix; Product; Price; Marketing Communication and Distribution

\section{INTRODUCTION}

61 wing to the diversified nature of the craft industry, there is no universally accepted definition of crafts. In SA, a craft product is defined as "the creation and production of a broad range of utilitarian and decorative items produced on a small scale, with hand processes being the significant part of the valueadded content". The production of goods uses a range of natural and synthetic materials (Department of Arts, Culture, Science \& Technology, 1997). Crafts are also known as handicraft or artisanal products. Artisanal products are defined as,

those produced by artisans, either completely by hand, or with the help of hand tools or even mechanical means, as long as the direct manual contribution of the artisan remains the most substantial component of the finished product. These are produced using raw materials from sustainable resources. The special nature of artisanal products derives from their distinctive features, which can be utilitarian, aesthetic, creative, culturally attached, decorative, functional, religiously and socially symbolic and significant (UNESCO,1997).

It can de deduced from the above definitions that the hand component during the production of craft products is useful in providing an understanding of what a craft product entails.

Craft products include a wide range of products such as home furnishings, jewellery, fashion and fashion accessories, novelties and gifts, including corporate gifts, garden and outdoor products, curios and collectibles, oneof-a-kind high-value individually made products, and indigenous artefacts, which are culturally derived products (Department of Labour, 2011; Department of Trade and Industry (DTI), 2005). Rogerson (2010) posits that craft products must be 80 percent handmade from different materials, which may include clay, natural fibres, beads, recyclable materials and textiles. 
Craft producers are driven by their desire to satisfy their artistic sensibilities, yet they find themselves in a situation where they have to balance their artistic vision and market demand. Some craft producers are more driven by the former, which implies that they fail to meet market demands since some of their artistic visions do not reflect what craft retailers and end consumers want (Obiri, 2002; Torres, 2002). As a result, some craft producers create products with no economic benefit derived from these products. For craft producers to derive an economic benefit, they need to gain an understanding of the markets (Hay, 2008).

There is an increasing demand for craft products globally, especially for home accessories and décor, gifts and products for garden and outdoor living which are simultaneously used for decorative and functional purposes (USAID, 2006). The rise in consumers' disposable incomes and the tendency to accessorise and re-style homes with unique articles are the major driving factors of the surge in demand for crafts and decorative products (Frost \& Sullivan, 2005). In SA, recent decades have seen the opening of many homeware stores such as PepHome, @Home, @ Home living space, and Mr Price Home as well as Woolworths Artistic Collection department, which operate from inside the Woolworths branches. All these retailers sell handcrafted products, which create opportunities for craft producers targeting craft retailers.

The next sections will address the problem statement and objectives of the study followed by the literature review and methodology adopted in this research.

\section{PROBLEM STATEMENT}

Small and medium businesses (SMEs) are important for economic growth through employment creation, skills development and poverty alleviation (Department of Sports, Arts, Recreation and Culture, 2007). The common characteristics of SMEs are that they are small in size and that they are owner managed. This has led to a situation where owner-managers are responsible for all business activities involving managing the business, purchasing, production, human resources, sales and marketing, financial management and so forth. As a result, marketing receives lip service at the expense of business performance (Horgath-Scott, Watson \& Wilson, 1996). A study by Huang and Brown (in Simpson \& Taylor, 2002) revealed that small b consider marketing as their major challenge, followed by human resources, general management and production and operations. SMEs face challenges with marketing of their products. They lack understanding of the market and cannot perform market need analysis. They are unable to segment the market and cannot successfully and effectively market their products (Van Scheers, 2011).

Lekhanya (2010) investigated the use of marketing by SMEs. The results of the research revealed that there was a lack of marketing knowledge and expertise and limited use of marketing strategies by the owners/managers of the rural SMEs. According to Radipere and Van Scheers (2005) the problems experienced by SME owners in conducting a successful business are market-related issues such as marketing, locality, lack of knowledge of the market, product demand and competition, which are associated with the industry in which the business operates.

Craft producers face numerous marketing-related challenges in SA. They lack understanding of what the market needs, which leads to an inability to formulate appropriate and competitive product and marketing strategies (Grobler, 2005). Craft producers often sell similar products that do not address market demands and they have difficulty in accessing the markets (Makhitha \& Bresler, 2011; Hay, 2008; Department of Sports, Arts, Recreation \& Culture, 2007:10). Craft producers also lack skills in product design, distribution and organisation management (DTI, 2005) and possess limited knowledge of the lifestyles and product preferences of their potential customers and the promotional strategies needed to target them (Littrell \& Miller, 2001). As stated in Urban-Econ Tourism (2010), craft producers copy each other's product designs and products which lack innovativeness and uniqueness. Because they are not informed about the market and are unable to produce the quality and quantity it demands, they cannot access the market. The purpose of this research is to investigate the marketing strategies of craft producers. Specifically the paper will address the following objectives:

- To determine the marketing strategies of craft producers in SA

- To identify challenges experienced by craft producers in SA 


\section{LITERATURE REVIEW}

\section{Marketing in SMEs}

SMEs fulfill a number of roles ranging from poverty alleviation and employment creation to international competitiveness (Nieman, Hough \& Nieuwenhuizen, 2003). According to Lekhanya (2010), SMEs have become a critical solution for starting and developing the standard of living in South Africa owing to the low economic growth, high unemployment and an unsatisfactory level of poverty in South Africa, particularly in the rural areas. The SMEs play a vital role in the economic development of a country (Muhammed, Char, Yasoa \& Hassan, 2010). SMEs are usually defined in terms of employment or turnover that they generate (Rogerson, 1999). SMEs are defined as firms with fewer than 250 employees or annual turnover of approximately R300 million.

Traditionally, marketing was associated with large businesses yet many research studies have been conducted (Gilmore, Carson \& Grant, 2001 and Simpson, Padmore \& Taylor, 2001) on SME marketing and have proven the importance of marketing for SME success (Lekhanya, 2010). Evidence shows that marketing is always underutilized and misunderstood by SME owner-managers (Horgath-Scott, Watson \& Wilson, 1996) and that SME marketing is restricted by resource constraints such as finance, personnel, perception of function, skills and attitude (Simpson \& Taylor, 2002).

However, SMEs are not exempted from marketing since they have to practice marketing in order to grow and survive (Horgath-Scott, Watson \& Wilson, 1996). Marketing plays a leading role in SMEs compared to other business functions in overall corporate planning (Brooksbank et al., 1999). SME marketers may consider marketing as a synonym of either advertising or selling (Lekhanya, 2010) yet basic marketing concepts such as segmentation, targeting, positioning, customer orientation and seeking for competitive advantage and applies to SMEs as well as large ones (Awan \& Hashmi, 2014).

Marketing forms the backbone of a business (French \& Harrison, 2004) and determines how big the market slice a business can get against the competitors. High performing small tend to give a higher priority to marketing and tend to use strategic marketing planning (Siu, 2000). Through marketing, a business aims to achieve competitive advantage by satisfying its customers more effectively and efficiently than its competitors which leads to higher profitability (Reijonen, 2010). The growth of SME is associated with a successful product-market strategy; how managers create and exploit market opportunities and cope with difficulties and a greater propensity to follow a strategy of focused differentiation and a lower propensity to compete on price (Horgath-Scott, Watson \& Wilson, 1996).

While traditional marketing is concerned with a planned process to identify market needs by formal research and through purposeful development of new offerings to the market place, SMEs involves informal, unplanned activity that relies on intuition and energy of the owner-manager (Blankson \& Stokes, 2002). SMEs neither conduct a situation analysis nor have any knowledge of marketing planning tools. They do less in-house market research and do not adopt a proactive approach in the planning approach to the future (Siu, 2000). They hold certain advantages such as employee loyalty, level of contact between the business and the customers, flexibility, speed of response, opportunity oriented and easy access to market information (Lotz \& Marais, 2007).

Since SME owners and managers experience challenges with marketing; lack of access to finance; business skills; and lack the knowledge, experience and time needed (Simpson \& Taylor, 2002), the practice of marketing planning is limited. SMEs adopt an informal marketing planning approach that relies on social and personal contact networks rather than formal approach requiring the application of these tools (Siu, Zhu \& Kirby, 2003). Planning is informal and short-term in nature (Siu, Fang \& Lin, 2004). They also do not consider marketing plans as essential for the survival of their business (Lotz \& Marais, 2007).

Marketing is as important for SMEs as it is for large ones. The strategic goal of marketing is to bring the right product to the right place at the right price with the right promotion (Mariotti, 2007). Large businesses have access to resources needed to market their products successfully while small ones lack such resources which impact on ability to market their products effectively. The practice of marketing by SMEs also differs from those of large 
businesses. According to Van Scheers (2011) SMEs ineffectively market their products, experience low product demand and also lack marketing knowledge. SMEs do not practice the same kind of marketing. SMEs conduct marketing research informally (Blankson \& Omar, 2002; Brooksbank et al., 1999). This research will adopt the McCarthy and Perreault's definition of marketing strategy to determine the marketing strategies used by craft producers.

Carter and Jones-Evans (2000) stated that SMEs engage in little marketing activity. Most SMEs have few resources to devote to marketing. Furthermore owners/managers who have no experience of marketing, prefer to devote their time to activities that are more familiar, for example, production, with the result that little time is spent on either marketing or selling activities (Carter \& Jones-Evans (2000).

\section{Marketing Strategy}

McCarthy and Perreault (1999) define marketing strategy as a marketing activity that specifies a target market and its related marketing mix elements/activities such as product, promotion, price and place (distribution). A marketing strategy is the means by which an organization sets out to achieve its marketing objectives (Brassington \& Pettitt, 2007). Walker, Mullins and Larréché (2008) further describe marketing strategy as specifying the target market for a particular product or product line and ensuring that all marketing mix elements are integrated for competitive advantage and tailored to meet customer needs. It determines how an business is going to compete against its major rivals. A marketing strategy is documented in a marketing plan which guides the day-to-day running of operational marketing activities. Marketing plans allow the evaluation of the delivery of value in each market segment continually and determines if delivery of value is in line with their proposed value propositions and marketing objectives, and their expectations of customers (Venter \& Jansen Van Rensburg, 2009). Large businesses are more likely to have a formal marketing plan than smaller businesses (Coviello, Brodie \& Munro, 2000).

\section{Marketing Mix}

The marketing mix elements include the product, promotion (marketing communication, price and place (distribution). They are also known as the four Ps (Venter \& Janse Van Rensburg, 2009). Marketing mix decisions must be consistent with the business strategies and should be altered from time to time in response to changes in the marketing environment (Ranchhod, 2004). The manner in which a business manages its marketing mix elements determines the success of the business (Ellis, 2005). Keh, Nguyen and Ping (2007) maintain that the utilization of information regarding marketing mix decisions, specifically the promotion and place elements, positively affect SMEs and partially mediate the relationship between entrepreneurial orientation and firm performance.

O’Dwyer, Gilmore and Carson (2009) investigated innovative marketing strategies in SMEs. The findings revealed that innovative practices are a key factor in profitability, growth and survival which requires that business be innovative in marketing activities such as target market decisions, product, marketing communication, price and distribution. In another study (Reijonen,2010), marketing practices of SMEs was studied and it was discovered that SMEs emphasized promotion and considered it as important for making the business known or informing potential customers about their businesses. Selling and sales promotion were also considered important elements of marketing. Businesses also understood segmentation and targeting as charting a customer base, informing and attracting potential customers and targeting and reaching the right customers. Businesses did not understand what positioning is. Product, price and place were considered less important while customer relationships were considered very important.

\section{Target Market}

Market segmentation is a process by which a market is divided into distinct subsets (segments) of customers with similar needs and characteristics (Lamb et al., 2011). The choice of a specific market segment determines which marketing effort will be directed toward each of the chosen market segments (Craven \& Piercy, 2009). Some craft producers with no understanding of the market assume that the needs and preferences of the market/s are the same (Grobler, 2005). Owing to foreign competition from countries such as China, which offer quality products at competitive prices, craft producers in SA would be better off moving away from mass production to producing high- 
end products (Department of Sports, Arts, Culture \& Recreation, 2007). However, this might mean that they will fail to supply customers, such as those in the medium- and lower-end markets, which buy in bulk and are concerned about price when buying.

Marketing, as a strategy, is based on a careful analysis of customers and competitors, and of the firm's resources and skills for competing in a specific market (Stokes \& Chen, 2009). Craft producers target their products to different market segments. These include retailers, corporate buyers that buy for business use such as decorations and as a gift to customers and tourists, which includes local and international tourists. Furthermore craft producers also target the general public, which consists of local consumers, who are not tourists (Department of Sports, Arts, Recreation \& Culture, 2007; Kaiser and Associates, 2005). Their ability to target these segments effectively is affected by the effectiveness of their marketing strategies.

\section{Product Strategy}

As part of the marketing strategy decisions, businesses make decisions regarding the products to be offered in the market as a proposition to satisfy the specific needs of the selected target markets. This involves making decisions on the nature of the products the organisation will offer, the breadth or diversity of the product lines, the level of technical sophistication and the target level of product quality relative to competitors (Walker et al., 2008). Product decisions also involve making decisions on matters such as the branding, packaging, product development and product improvements and service level decisions (Alsen, 2007). Brassington and Pettitt (2007:) indicate that whether a product is a totally new innovation, an update of a familiar product or an imitation of a competitor's product, it needs careful planning and development to ensure that it meets customers' needs and wants, that it has a significant competitive advantage and that it is accepted within the marketplace. Marketing and branding of craft products has been identified by the Department of Sport, Arts, Culture and Recreation (2007) as one of the obstacles towards the success of craft producers. Some of the craft products are generic items found across many craft producers and retailers (Department of Sport, Arts, Culture and Recreation, 2007; Kaiser \& Associates, 2005)). There is a tendency among craft producers to produce products that are not specific to any particular target market. They produce generic items instead of producing products that are unique and also specific to a particular target market. Majority of craft products are standardized and similar cross producers and retailers, leaving very little to distinguish between products from different suppliers (Cape Craft and Design Institute (CCDI), 2008).

Some retailers stock products of higher quality and that are unique. However, these products are highly priced and are therefore unaffordable to consumers (Greene, Hammett \& Kant, 2000). The ability of the business to innovate or produce new product designs plays an important role in facilitating and expanding market access. This also entails the ability of a business to diversify the production ranges as well as offering up-to-date custom-made products (Rogerson, 2000). Retailers stock products of higher quality and that are unique. However, these products are highly priced and are therefore unaffordable to local resident consumers (Greene, Hammett \& Kant, 2000). The ability of craft producers to innovate or produce new product designs plays an important role in facilitating and expanding market access. This also entails the ability of a business to diversify the production ranges as well as offering up-todate custom-made products (Rogerson, 2000). Other product attributes for craft products include design, stylistic qualities, production (standardization and individualization), size of products, materials and function (Moreno \& Littrell, 2001).

Craft producers tend to produce many products and also develop many product lines despite the size of their business. For example, they produce between 1 and 20 product lines. This could cause a problem for them since many of these businesses are one-man businesses; it may therefore be impossible for them to manage many product lines. Product sales range from R100 000 to R3,5 million per annum (Department of Sport, Arts, Culture and Recreation, 2007:107). The design, styling, quality, packaging and brand of a product determine the performance of a product (Brennan et al., 2007; Wright, 2004). Product design refers to the means by which the functionality of the product is allocated to the physical components of the product (Khan \& Creazza, 2009). Product quality encompasses many elements. First, it refers to the fact that the product must meet customer specifications. This implies that the product must have all-important features as specified and expected by the customer. Second, businesses must ensure total quality management and customer satisfaction with every element of the product across the product supply chain to ensure customer value. 
Retailers rate product quality, e.g. product is exciting and attractive, styling and design as well as product distinctiveness as the most important product aspects that determine whether they will buy from craft producers or not (Makhitha, 2013). Consumers on the other hand, prefer quality, product style, price and originality as the main features considered when buying crafts (Kaizer \& Associates 2005:31). Product quality helps differentiate the business from others and can be achieved through certification, in terms of possession of a quality mark or symbol, possession of a regional label and specification in terms of production, delivery and traceability or link to a culture and attraction in terms of design, texture, appearance, price and personal attention (Cawley et al., 1999) product.

\section{Marketing Communication}

Marketing communication is a means by which an organisation attempts to inform, persuade and remind consumers, directly or indirectly, about the products and brands that they offer (Keller, 2009). Marketing communication becomes the "voice" of the organisation and its brands; and this is also a channel whereby it can establish a dialogue and build relationships with its customers. Businesses can use various channels of marketing communication to achieve their communication goals. The channels used to communicate with the market are known as the marketing communication mix; and they comprise: advertising, sales promotion, public relations, personal selling, exhibitions, telemarketing, and direct marketing tools (Lamb, Hair, Mc Daniel, Boshoff, Terblanche, Elliot and Klopper, 2010; Dwyer \& Tanner, 2009).

Marketing communication enables marketers to combine all of their communications in order to plan and create a coherent and synergistic approach (Zimuto, 2013). Marketing communication appreciates the significance to marketing strategy and corporate branding of new communication tools, such as direct marketing, Internet marketing, or different types of sales promotions (McGrath, 2005). Each of the channels entails a specific technique to communicate with consumers. For example, advertising uses various media, such as the print media, broadcasting, and the Internet; while sales promotion uses tools, such as discounts, coupons, displays and demonstration - in order to reach its customers (Cassim, 2013).

The most common forms of marketing communication for craft are the use of printed materials such as brochures, pamphlets and business cards; direct sales; exhibition; personal networks; word-of-mouth and trade fairs (Department of Sport, Arts, Culture and Recreation, 2007). The use of brochures is supported by the fact that it is cheaper and that the Gauteng government, through its agencies such as Gauteng Economic Propeller (GEP) do finance SMEs for a certain quantity of printed brochures. This means that each qualifying SME can get brochures printed for free once in a lifetime of their business. They are also expected to have brochures when they participate in an exhibition in order to hand out to potential customers, although these are usually printed by the exhibition sponsor.

According to Van Scheers and Radipere (2008) advertising aid SMEs to differentiates their businesses from those of competition. Clow and Baack (2004) highlighted that most SMEs do not have the money to send a marketing message to millions of potential customers. Epstein (2006) argues that word-of-mouth describes social network effects not carried by an intermediate product, but actually implemented directly. Lekhanya's (2010) study found that local advertising, personal selling and brochures as being the most commonly used promotion methods.

Written materials such as pamphlets, letters, advertisements, new items forms (forms drafted by the selling company and completed by the salesperson) are also useful sources of information (Sternquist \& Chen, 2006). It is important for the craft producers to understand the specific information craft retailers look for when souring information. For example, fashion retailers look for information on product quality, types of merchandise carried, product or merchandise styles, colour, fabrics and fibre, care, service, and warranties and guarantees (Clodfelter, 2008).

The utilisation of the Internet by craft producers is very low and the opportunities associated with the Internet have not been fully exploited by craft producers in SA (Department of Sport, Arts, Culture and Recreation, 2007). However, Dhurup and Makhitha (2014) found that the Internet is moderately used by craft producers. The development in IT has brought about opportunities for businesses to reach their supply chain partners at arm's length. Businesses have generally relied on traditional forms of communication such as advertising and use of salespersons. The introduction of the Internet as an e-commerce technology has changed the way businesses 
communicate with each other. The Internet is used for many purposes, including email, accessing product and component information, searching for new suppliers, gathering information about current suppliers, providing information to suppliers, gathering competitive information, online ordering and so forth (Deeter-Schmelz \& Kennedy, 2002; Osmonbekov et al., 2002).

\section{Pricing Craft Products}

Pricing is another challenge that is facing craft producers. There is also a lack of data on pricing of craft products. However, there are wide perceptions that in the craft industry, prices are highly negotiable. There is also a belief that some craft customers, including consumers, trade and corporate, exploit craft producers and expect to pay lower prices that are not profitable to the producers (Phillip, 2006). The prices of craft raw materials and equipment are high, making it difficult for craft producers to meet the pricing levels of the international suppliers. Production costs are also very high, contributing to high selling prices (Department of Sport, Arts, Culture and Recreation, 2007). Craft producers can adjust their prices by discounting prices for certain products depending on the quantity bought, the length of time a buyer has been buying from the organisation, the location of a customer and whether or not a customer is buying with cash (Bingham et al., 2005).

Pricing plays a very important role for both the producers and the retailers since it affects the profit they make. It determines if customers will buy products from the producer or not (Lamb et al., 2010). The ability of a craft producer to charge the appropriate price and their ability to negotiate prices to the satisfaction of customers will benefit both parties. There are many craft producers, locally and internationally, varying in terms of prices charged and products offered which provides customers with a variety of suppliers from whom they can source craft products (Department of Sports, Arts, Culture and Recreation, 2007). There is also a growing trend for retailers nationally and internationally to source products from cheaper suppliers in Asia, such as China and Taiwan. This implies that the inability of local craft producers to price their products competitively will affect their ability to attract such retailers locally.

\section{Distribution of Craft Products}

Craft products are distributed through various channels of distribution such as direct sales; craft markets; small retailers/boutique; wholesalers, which include importers, exporters and agents; national retailers and e-commerce. The direct sales; craft markets and small retailers have been the main forms of retailing in the craft industry for over a decade (DTI, 2005). The utilization of various craft retail channels could stem from the fact that craft products are targeted at various market segments. Another reason could be that not all retailers are accessible by craft producers. For example, the craft retail activities are more accessible by white craft producers who sell their craft products through popular craft retail such as popular craft markets, interior design shops and galleries while craft producers owned by blacks and coloured people are mainly sold through informal markets due to limited access to capital, resources and technology (Hu \& Yu, 2007; Wesgro, 2000).

Craft markets are considered the first point of entry for craft producers who want to retail their goods (Department of Art, Culture, Science and Technology, 1998). Flea markets are also considered one of the best places to be for tourists (SA Tourism, 2009), which justifies why some craft producers sell at the flea markets. However, craft producers selling at the flea and craft markets are those failing to develop new and unique products that can warrant a space in craft retail stores (Sellschop, Goldbalatt \& Hemp, 2005). Some craft producers rely on festivals and shows which help boost their earnings in a short period of time (Department of Arts, Culture, Science and Technology, 1998).

Craft retail is the most dominant activity in the craft value chain followed by production and design. They sell a diverse range of products with the dominant form of retail being the commercial retail outlets, galleries and producer-reseller outlets (Kaiser \& Associates, 2005). Retailers differ according to product assortments, product characteristics, prices and quality and size of a shop (Moreno \& Littrell, 2001). They also target different target markets which influences the type of products bought. For example, retailers located at international airports and major shopping centres such as Sandton City carry expensive merchandise targeted mainly at high income earners and international tourists, while stores like Mr Price carry low priced merchandise targeted at local consumers who 
buy craft mainly for decorations. This implies that the buyer behaviour of craft retail will be different, including the fact that they might consider different supplier evaluation and selection criteria. Retailers are also different in the sense that some such as Mr Price, and certain furniture stores are chain stores while others are small independent stores with one or two branches (Makhitha, 2013).

\section{METHODOLOGY}

The study adopted a descriptive approach using a quantitative survey method. The population for the study included craft producers producing different types of products in Gauteng SA. Gauteng province, one of the major urban provinces in South Africa has a substantial concentration of craft businesses (Kaiser \& Associates, 2005). Owing to the difficulties of identifying craft producers and the fact that they are not easily accessible, the study adopted a convenience sampling. Ease of reach, and cost were also considered in choosing the convenience sampling method (Cooper \& Schindler, 2006). There was also no accessible database that could have been used to access craft producers, the reasons why convenience sampling was adopted. The units of elements consisted of craft producers who are either owners or managers of the business. Craft producers making different types of craft products and are operating in Gauteng Province were targeted. Craft producers that were located in flea and craft markets were targeted for the sample. Flea and craft markets are the places most visited by tourists and other consumers looking for craft products (SA Tourism 2009).

A questionnaire was designed using the literature from previous studies, including government sources such as reports from the South African Craft Industry and DTI. The questionnaire items measured five constructs: market segmentation, product development, marketing communication, pricing and distribution consisting of 30 items. The Likert-scale question format was used with 1 denoting strongly disagree, 2 denoting disagree, 3 denoting moderately agree, 4 denoting agree and 5 denoting strongly agree. There were four items measuring target market, eight items measuring product development, nine items measuring marketing communication, four items measuring pricing and two items measuring distribution. An additional item measuring marketing planning was also included to determine if craft producers prepared a marketing plan. There were two demographics items including length of time the business was in operation and number of workers employed by each business.

Data were collected from either owners or managers of the businesses. The fourth-year Bachelor of Technology Logistics students from a University of Technology were used to collect data. Students were trained to perform fieldwork. A total of 250 questionnaires were completed, however, only 244 of them were considered usable, yielding a response rate of 98 percent. The other questionnaires were discarded because they were either incomplete or many had missing answers.

Data analysis was carried out using SPSS version 22.0 for Windows. Various statistical analyses were undertaken including descriptive analysis of the sample composition, correlations and factor analysis. The reliability analysis was also computed. The purpose of using descriptive statistics was to determine the extent to which craft producers practice marketing strategies and to determine challenges that they face in the industry. Factor analysis was conducted to ascertain whether the variables developed from a review of the literature could, in fact, be grouped into meaningful dimensions to describe the marketing strategy practices and challenges of craft producers. The main purpose of factor analysis is to define the underlying structure among variables in the analysis (Hair, Black, Babin \& Anderson, 2010). The objectives of the research were achieved using the above statistics, since the researcher was able to determine the practices and challenges in the craft industry.

\section{RESULTS AND DISCUSSION}

\section{Descriptive Statistics}

The majority of samples have been in existence for a period of between three and five years $(32 \%, \mathrm{n}=79)$ followed by those who have been in operation for between 6 and 10 years $(23 \%, n=57)$. Over 48 percent $(n=119)$ employs between 2 and five persons followed by those employing one person $(42, \mathrm{n}=102)$. Businesses develop a marketing plan as shown by 54 percent $(n=131)$ who indicated that they do design a marketing plan for their business. 
Table 1. Descriptive statistics

\begin{tabular}{|c|c|c|c|}
\hline Construct & Scale item & Mean & $\begin{array}{l}\text { Standard } \\
\text { deviation }\end{array}$ \\
\hline \multirow{5}{*}{ Target market } & It is difficult to locate customers who want our products & 3.29 & 1.289 \\
\hline & We face challenges selling to retailers & 3.00 & 1.277 \\
\hline & There is lack of demand for craft products & 3.25 & 1.244 \\
\hline & We have approached retail business in an attempt to sell to them & 3.77 & 1.131 \\
\hline & Target different market segments with our products & 3.09 & 1.160 \\
\hline \multirow{10}{*}{$\begin{array}{c}\text { Product } \\
\text { development }\end{array}$} & Develop new products to keep up with the changes in the market & 4.00 & 1.164 \\
\hline & Improve some of our products by adding new features & 4.28 & .997 \\
\hline & Develop unique products differentiated from those of competitors & 4.20 & 1.128 \\
\hline & Bring in new products from time to time & 4.09 & 1.085 \\
\hline & We develop different products for each market segment & 3.55 & 1.245 \\
\hline & We sell similar products for different market segments & 3.21 & 1.221 \\
\hline & Products are branded & 2.68 & 1.294 \\
\hline & Products are unique/one of a kind & 3.95 & 1.187 \\
\hline & Products are of high quality & 4.19 & 1.053 \\
\hline & There are different product ranges to choose from & 4.11 & 1.181 \\
\hline \multirow{9}{*}{$\begin{array}{c}\text { Marketing } \\
\text { communication }\end{array}$} & Have access to own Internet & 2.56 & 1.460 \\
\hline & Access Internet at the internet café & 2.73 & 1.397 \\
\hline & Use Internet to sell and advertise the products & 2.41 & 1.371 \\
\hline & Use of email to communicate with customers & 2.60 & 1.432 \\
\hline & Internet is useful for our businesses & 2.81 & 1.453 \\
\hline & Use of email to communicate with suppliers & 2.52 & 1.395 \\
\hline & We provide information about our products & 3.89 & 1.280 \\
\hline & We use promotional tools such as brochures, pamphlets to promote our products & 3.03 & 1.381 \\
\hline & We use internet to advertise our products & 2.56 & 1.352 \\
\hline \multirow{4}{*}{ Pricing } & We face difficulties pricing our products & 2.85 & 1.337 \\
\hline & Prices charged to international customers are higher & 3.15 & 1.342 \\
\hline & Prices are highly negotiable & 3.66 & 1.173 \\
\hline & We charge different prices for different customers depending on how they negotiate & 3.49 & 1.222 \\
\hline \multirow{2}{*}{ Distribution } & We sell products directly to customers from our factory & 3.62 & 1.326 \\
\hline & We sell products at the fleamarkets & 3.90 & 1.290 \\
\hline
\end{tabular}

\section{Reliability Analysis}

Reliability analysis (Cronbach alpha) was computed to determine the internal consistency of the market segmentation, product development, marketing communication, pricing, distribution and product attributes scales. The Cronbach $\alpha$ for the composite scale was 0.848. Malhotra (2010) deemed the Cronbach $\alpha$ of 0.70 to be satisfactory. The Cronbach $\alpha$ of individual scales ranged from 0.835 to 0.854 . The reliability of the scales is satisfactory and consistent with other studies (Swanson, 2004).

Content validity was also established through a pre-test of the questionnaire with three academics. A pilot test was conducted in the field with $50 \mathrm{craft}$ producers. Question wording, formatting and content were adapted after the pretest and pilot test stages. Content validity is the representativeness of the content of the measurement instrument (Malhotra, 2010). The construct validity of the scale was established through the exploratory factor analysis. Since there were no cross-loadings among the factors, this provided evidence of discriminant validity as suggested by Zikmund \& Babin (2007).

\section{Factor Analysis}

Table 2 reports on the mean scores and standard deviation of the five constructs: product development, quality assurance, Internet adoption, finance and training and development. The results show that craft businesses place emphasis on product development as shown by the high mean score for product development. Craft producers seem to pay less attention to marketing communication, as can be seen by the low mean scores on this construct. Marketing communication is important for any business, regardless of size. 
Factor analysis is used to condense the information in a number of original variables into a smaller set of new, composite dimensions or factors, with a minimum loss of information. The researcher can search and define the fundamental constructs or dimensions assumed to underlie the original variables (Hair, Black, Babin \& Anderson, 2010).

According to Hair et al., (2010), a loading of less than 0.5 can be accepted depending on the sample size (Hair et al., 2010). Items with factor loadings of 0.45 were considered part of the group variables and those of less than 0.40 were omitted. Hair et al., (2010) consider factor loadings of 0.30 acceptable. However, factor loadings depend on the sample size. For example, Stevens (Field \& Miles, 2010) indicated that, for a sample of 200, a factor loading of 0.364 is acceptable and for a sample of 1000 , a factor loading of 0.162 is acceptable. Although variables with a loading of 0.3 can be interpreted, it should be noted that the higher the loading, the more the variable is a premeasure of the factor. The cut-off of the variable loading can be determined by the homogeneity of scores where, if homogeneity is suspected, interpretation of lower loadings is warranted (Tabachnick \& Fidell, 2001).

Table 2. Factor analysis

\begin{tabular}{|c|c|c|c|c|c|c|c|}
\hline & \begin{tabular}{c|c|} 
Factor 1 \\
Marketing \\
communication
\end{tabular} & \begin{tabular}{c|} 
Factor 2 \\
Product \\
development
\end{tabular} & $\begin{array}{l}\text { Factor } 3 \\
\text { Products } \\
\text { attributes } \\
\end{array}$ & $\begin{array}{c}\text { Factor } 4 \\
\text { Target } \\
\text { market }\end{array}$ & $\begin{array}{l}\text { Factor } 5 \\
\text { Price }\end{array}$ & \begin{tabular}{|c|} 
Factor 6 \\
Market access \\
challenges
\end{tabular} & $\begin{array}{c}\text { Factor } 7 \\
\text { Distribution }\end{array}$ \\
\hline $\begin{array}{l}\text { Use of email to } \\
\text { communicate with } \\
\text { customers }\end{array}$ & .877 & .014 & .078 & -.062 & -.016 & .063 & .023 \\
\hline $\begin{array}{l}\text { Use internet to sell and } \\
\text { advertise the products }\end{array}$ & .831 & .039 & .064 & -.010 & -.086 & .061 & -.051 \\
\hline $\begin{array}{l}\text { Internet is useful for our } \\
\text { businesses }\end{array}$ & .825 & .030 & .054 & .154 & .100 & .050 & .100 \\
\hline $\begin{array}{l}\text { Use of email to } \\
\text { communicate with } \\
\text { suppliers }\end{array}$ & .794 & -.020 & .050 & .090 & -.022 & -.097 & .023 \\
\hline $\begin{array}{l}\text { Have access to own } \\
\text { internet }\end{array}$ & .765 & -.040 & .124 & .034 & -.057 & .014 & .079 \\
\hline $\begin{array}{l}\text { Use Internet to advertise } \\
\text { our products }\end{array}$ & .745 & .089 & .088 & .174 & .020 & -.037 & -.113 \\
\hline $\begin{array}{l}\text { Access internet at the } \\
\text { internet café }\end{array}$ & .698 & .110 & .035 & -.144 & .015 & .038 & .158 \\
\hline $\begin{array}{l}\text { Use promotional tools such } \\
\text { as brochures, pamphlets to } \\
\text { promote our products }\end{array}$ & .559 & .092 & -.104 & .440 & .085 & -.164 & -.095 \\
\hline $\begin{array}{l}\text { Develop unique products } \\
\text { from those of competitors }\end{array}$ & -.003 & .844 & .209 & .094 & .063 & -.050 & .123 \\
\hline $\begin{array}{l}\text { Develop new products to } \\
\text { keep up with the changes } \\
\text { in the market }\end{array}$ & .032 & .798 & .059 & .206 & .094 & -.022 & .119 \\
\hline $\begin{array}{l}\text { Improve some of our } \\
\text { products by adding new } \\
\text { features }\end{array}$ & .043 & .774 & .104 & .230 & .251 & .030 & -.006 \\
\hline $\begin{array}{l}\text { Bring in new products } \\
\text { from time to time }\end{array}$ & .087 & .730 & .229 & .051 & -.088 & .073 & .122 \\
\hline $\begin{array}{l}\text { Products are unique/ one } \\
\text { of a kind }\end{array}$ & .171 & .331 & .685 & .011 & .155 & -.052 & .064 \\
\hline $\begin{array}{l}\text { Products are of high } \\
\text { quality }\end{array}$ & .111 & .243 & .672 & .093 & .121 & .214 & .158 \\
\hline $\begin{array}{l}\text { There are different product } \\
\text { ranges to choose from }\end{array}$ & .038 & .205 & .629 & .189 & .320 & .004 & .188 \\
\hline
\end{tabular}

(Table 2 continued on next page) 
(Table 2 Continued)

\begin{tabular}{|c|c|c|c|c|c|c|c|}
\hline & \begin{tabular}{|c|} 
Factor 1 \\
Marketing \\
communication \\
\end{tabular} & $\begin{array}{c}\text { Factor } 2 \\
\text { Product } \\
\text { development } \\
\end{array}$ & $\begin{array}{c}\text { Factor } 3 \\
\text { Products } \\
\text { attributes } \\
\end{array}$ & $\begin{array}{c}\text { Factor } 4 \\
\text { Target } \\
\text { market }\end{array}$ & $\begin{array}{c}\text { Factor } 5 \\
\text { Price }\end{array}$ & \begin{tabular}{|c|} 
Factor 6 \\
Market access \\
challenges
\end{tabular} & $\begin{array}{c}\text { Factor } 7 \\
\text { Distribution }\end{array}$ \\
\hline $\begin{array}{l}\text { Products are branded } \\
\text { products }\end{array}$ & .311 & -.015 & .456 & .190 & -.131 & -.061 & -.320 \\
\hline $\begin{array}{l}\text { We target different market } \\
\text { segments with our product }\end{array}$ & .082 & .150 & .140 & .784 & -.042 & .186 & .126 \\
\hline $\begin{array}{l}\text { We develop different } \\
\text { products for each target } \\
\text { market }\end{array}$ & .017 & .224 & .155 & .713 & .051 & .043 & .065 \\
\hline $\begin{array}{l}\text { We provide information } \\
\text { about our products }\end{array}$ & .174 & .351 & .050 & .500 & .198 & -.082 & .318 \\
\hline $\begin{array}{l}\text { We charge different prices } \\
\text { to customers depending on } \\
\text { how they negotiate }\end{array}$ & .013 & .086 & .105 & .009 & .850 & .178 & .031 \\
\hline $\begin{array}{l}\text { Prices are highly } \\
\text { negotiable }\end{array}$ & -.076 & .132 & .194 & .069 & .815 & .045 & .160 \\
\hline $\begin{array}{l}\text { It is difficult to locate } \\
\text { customers who want our } \\
\text { product }\end{array}$ & -.027 & .051 & -.102 & .069 & .044 & .763 & -.220 \\
\hline $\begin{array}{l}\text { There is lack of demand } \\
\text { for our products }\end{array}$ & .055 & -.034 & .074 & .000 & .143 & .735 & .140 \\
\hline $\begin{array}{l}\text { Prices charged for } \\
\text { international customers } \\
\text { are higher }\end{array}$ & -.035 & -.013 & .333 & .125 & .033 & .498 & .328 \\
\hline $\begin{array}{l}\text { We sell products at the } \\
\text { flea market }\end{array}$ & .153 & .154 & .050 & .098 & .193 & .014 & .767 \\
\hline $\begin{array}{l}\text { We sell products directly } \\
\text { to customers from our } \\
\text { factory/space }\end{array}$ & -.021 & .274 & .269 & .247 & -.024 & .042 & .562 \\
\hline $\begin{array}{l}\% \text { of variance explained } \\
\text { per factor }\end{array}$ & 23.65 & 15.85 & 7.02 & 5.17 & 4.55 & 4.13 & 3.95 \\
\hline Cumulative $\%$ of variance & 23.65 & 39.52 & 46.52 & 51.70 & 56.25 & 60.39 & 64.34 \\
\hline \multicolumn{8}{|l|}{$\begin{array}{l}\text { Factor reliability } \\
\text { (Cronbach's Alpha } \alpha) .843\end{array}$} \\
\hline Eigen values & 6.151 & 4.121 & 1.826 & 1.345 & 1.183 & 1.076 & 1.027 \\
\hline
\end{tabular}

The first factor usually has the highest eigenvalue while the second factor has the second largest. Eigenvalues measure the percentage of variance in the variables contained in a factor that are explained by the factor. The sum of the eigenvalues represents the total amount of variance explained by the analysis whilst the ratio of each of the eigenvalues to the sum indicates the percentage of variance explained by the relevant factor. Factors with eigenvalues larger than 1 are retained since those with eigenvalues less than 1 are regarded as explaining less than one variable's worth of variance (Hair et al., 2010). Since factor analysis is also run to group the variables, factors are treated as new variables representing combinations of the original variable. The values for each of the variables are calculated and are known as the factor scores (Sudman \& Blair, 1998).

The principal component analysis method was utilised, with Varimax rotation method. Selection of this orthogonal rotation method with Kaiser normalisation was aimed at producing factors that are uncorrelated, leading to high factor interpretability. The Bartlett's test was significant at $\mathrm{p}<0.000$, which implied that the data set is not an identity matrix with zero correlations since variables are correlated. This confirmed that a factor analysis procedure could be applied in the study. Moreover, the Bartlett's test produced a chi square value $\left(\chi^{2}\right)$ of 2665.510 and a KMO value of $0.843(>0.50)$, further confirming that it is appropriate to conduct factor analysis.

Several default measures were employed in the factor extraction procedure for this study. In line with Zikmund and Babin (2007), the default measure was to use the eigenvalue ( $\geq$ than 1 ) criteria, and the percentage total variance contribution that is considered significant. In addition, factor loadings $(\geq 0.50)$, percentage of variance explained, and the scree plot criterion guided the extraction of factors. The total variance explained by the extracted factors was 64.34 percent, indicating that the other 36 percent is accounted for by extraneous variables that do not constitute part 
of this study and may be investigated in the future. A threshold of 0.46 to 0.78 was maintained on the communalities, as well as a cut-off point of 0.30 on the item-to-total correlations, as guided by Kim and Mueller (1978). This resulted into four items being dropped from factor analysis after they loaded unsatisfactory in the initial scale refinement procedure, suggesting that those items may be incapable of differentiating between factors. This procedure resulted in the extraction of a clear seven factor structure. Factors were labelled marketing communication, product development, product attributes, target market, price, market access challenges and distribution respectively. Table 3 shows the results of the rotated factor analysis procedure.

Factor 1 was labelled marketing communication and consisted of nine items loading favourably. The factor explained 23.65 percentage of total variance. High factor loadings were obtained ranging from .835 and .841 as well as communalities of between .54 and .78 thus confirming the internal validity of the factor. The high loading on this factor reveals that marketing communication is important for craft and that craft producers should formulate a marketing communication strategy for their businesses and products. Marketing communication is one of the major challenges facing craft producers in South Africa (Department of Sport, Arts, Recreation and Culture, 2007). Craft producers are also known to have moderate adoption of Internet (United Nations Industrial Development Organization, 2008; Batchelor \& Webb, 2002).

The next factor, factor 2, loaded four items and was named product development. Items consisted of "develop unique products from those of competitors", "develop new products to keep up with the changes in the market", "improve some of our products by adding new features" and "bring new products from time to time". This factor contributed 15.85 percent to the percentage of total variance. The factor loading for individual items ranged from .842 to .844 and the communalities of between .46 to .78 , which also confirms the internal validity of the factor. This implies that craft producers adapt their products in response to customer needs and preferences as suggested by Al-Askari (2011) that business must develop and create new products that meet the needs and preferences of customers. Furthermore, making frequent changes on products is necessary for craft producers to adapt to changing needs and trends in the craft market (Grobler, 2005)

Factor 3, was named product attributes since items loading in this factor closely related to the attributes of the product. It loaded four items such as "products are unique/one of a kind", "products are of high quality", "there are different product ranges to choose from" and "products are branded". The total percentage of variance for this factor was 7.02 percent. The high factor loading of .841 to .852 as well as communalities of .46 and .63 were obtained which further confirms the internal validity of the factor. Consumers consider quality, product style, price and originality as the main when buying crafts (Kaizer \& Associates 2005). Makhitha (2013) found that craft retailers rate product quality, exciting and attractive product, styling and design as well as product distinctiveness as the most important product. This implies that craft producers must determine the product attributes most important to their target market before they could develop products. They must adapt their products in response to customer needs and preferences by continuously developing and creating new products that meet the needs and preferences of customers (Al-Askari 2011). Craft producers that operate from the craft and flea markets are known to lack the knowledge of product development with regard to new product designs, resulting in many similar products being sold by craft entrepreneurs on the same premises (Sellsschop, Goldblatt \& Hemp (2005). Frequent changes in product design are necessary to complement the changing trends and needs of the craft market (Grobler, 2005).

The next factor is factor 4. It loaded three items and explained a total percentage of variance of 5.17 percent. The items loading in this factor included "we target different market segments with our products","we develop different products for each target market" and we provide information about our products". The factor was named target market. The three items had high loadings of .840 to .844 and communalities of .46 to .71 . The high loadings confirm the validity of the factor. Craft producers target various customers including consumers, tourists, corporate and the trade. They therefore need to determine the needs of each market segment to decide if different products should be developed for different market segments.

Factor 5 loaded two items relating to price and was named price. The two items were "we charge different prices to customers depending on how they negotiate" and "prices are highly negotiable". The total percentage of variance explained by these factors was 4.55 percent. High factor loadings were obtained ranging from .846 to .847 as well as the communalities of .756 and .774 also confirming the internal validity of the factor. Pricing of craft producers is 
one of the major challenges facing craft producers in South Africa. Craft producers need to attend training on how to cost their products so that they can set prices that are competitive and profitable for their businesses.

Factor 6 loaded three items including "it is difficult to locate customers who want our products", "there is lack of demand for our product" and "prices charged for international customers are higher". Lack of access to market poses a challenge for craft producers in South Africa (Kaiser \& Associates, 2005) which is why some of the craft producers live on the breadline instead of running profitably. There were high factor loadings for the items of between .848 and .854 and the communalities of between .590 and .774 . These confirmed the internal validity of the factor.

The factor was named market access challenges. It contributed 4.13 percent of the total variance. The last factor loaded two items and was named distribution. It contributed 3.95 percent of the total variance. The two items included "we sell products at the flea market" and "we sell products directly to customers from our factory/space". There were also high factor loadings of .844 each and communalities of .527 and .685 which implies the internal validity of the factor. The fleamarket is a major place consumers and tourists visit looking for crafts which support why some craft producers sell at the flea markets (SA Tourism, 2009). Craft producers also lack access to the retail market segment which is why they sell directly to consumers at the fleamarket and factory (Kaiser \& Associates, 2005).

\section{CONCLUSION}

\section{Recommendations and Limitations}

Craft producers face challenges with marketing their products. They lack a clearly defined target market and sell to every customer that comes along. They also do not determine which products to sell to which target market. Different target market have different needs, which implies that craft producers need to determine the needs for each of the target markets and decide which to target. Should they target different market segments, they would need to ensure that they are able to offer products that can meet the needs of these target markets.

Although craft producers claim to develop new products and improve existing heir products from time to time, it is difficult to notice since most of the products are similar across craft producers. Craft producers also indicated that they brand their products produce products of higher quality and offer different product ranges. Branding their products as well as offering high quality products would create an advantage for them since they would be able to differentiate themselves from their competitors. However, offering different product ranges, while it can be an advantage, would disadvantage them since they are small and lack necessary resources needed for them to produce different ranges of products. They would need to focus on a limited product range for a specific and defined target market.

Craft producers also do not have a formal pricing structure. Instead prices are negotiated from time to time which means that customers pay different prices for the same item. This is detrimental to their profitability. While it is important to negotiate prices, they need to set prices that would enable them to generate profitability for their businesses. Craft producers should consider offering or negotiating discounts based on quantities bought. Prices should be compared with those of other craft producers. Information about the prices set by other craft producers can be collected by checking prices of competitors at retail shops or by visiting competitors' workshops to check and evaluate their prices.

With regard to distribution, craft producers fail to access the formal market such as selling through retailers. They therefore resort to selling through informal channels such as the fleamarket and directly from the production space (factory). The disadvantage with the use of fleamarket and factory space is the fact that some cannot afford to rent a space at the fleamarket. Furthermore, customers might also not know where they operate from, which implies that they cannot be accessed. The use of marketing communication strategies could better craft producers' position but that would require that they have resources, especially financial ones to promote their products. From table 2, it can be seen that craft producers do supply information about their products to customers. They use promotional elements such as brochures and pamphlets; however, Internet adoption is still not effectively used. Craft producers do make 
use of the internet, although moderately so. They should continue using brochures and pamphlets since these are affordable means of marketing communication.

The Internet, while only moderately used by craft retailers, can also be used as a good method of conveying information to craft retailers. Craft producers must improve their use of the Internet to increase the image of their organisation and products, and also encourage retailers to adopt the use of the Internet. There are many websites such as Buy Africa, Arts Link and SA Arts that craft producers are able to use to market their products. SA Handmade and CCDI also publicise craft producers on their websites, which is something craft producers can take advantage of. Craft producers can use the Internet for developing their own websites, which can be expensive, or by using craft-related public websites such as those mentioned above.

The use of promotional videos or CDs can also be adopted by craft producers, who will be able to control how the product is made and tell the story of their products. This is useful for retailers who would then be able to assess the products at their own convenience and may also make suggestions as to the specifications of the product they order. Craft producers can distribute copies of videos or pictures of products to craft retailers via email, which is less costly and less time consuming.

It is important to note that craft producers lack market access as supported in this study. They indicated that there is lack of demand for their products and that it is difficult for them to locate customers who need their products. These could be due to the fact that they lack the proper marketing strategy that would guide them on who to target and how to decide on the product, price distribution and marketing communication elements for the chosen target market. Craft producers would therefore need to decide on who they want to target with their products, determine their needs and then formulate a marketing mix element strategy to reach the target market.

Craft producers need access to government provided support programmes to target SMEs. It will also be necessary for government to establish a public craft website where craft producers can market their products. This website could be used to list craft producers and their products as well as their contact details. However, it is essential that government make this service accessible to the majority of crafters and not only a handful, as is currently the case.

Government can also establish a newsletter or electronic newsletter targeted mainly at craft retailers, in which the various craft producers are listed. This could be useful for craft retailers to identify craft producers and to gain their contact details. It is imperative that such a marketing vehicle target not only a few but the majority of craft producers so that as many craft retailers as possible have a chance to appear in the newsletter.

The study focused on craft producers operating in Gauteng and not those from other provinces; another study could investigate craft producers in other provinces. Further studies could also investigate consumer behaviour when buying crafts which will provide information necessary for the formulation of marketing strategies.

\section{AUTHOR BIOGRAPHY}

KM Makhitha is an associate Professor at the University of South Africa and the HOD of Marketing and Retail Management. E-mail: makhikm@unisa.ac.za

\section{REFERENCES}

AL-Askari A.H. (2011). The impact of entrepreneurship and innovation on developing the marketing strategy in business organizations: an analytical study. Journal of Business and Retail Management Research 5(2):105-117.

Alsen, K.J. (2007). Strategic marketing: An applied perspective. Boston: McGraw-Hill Irwin.

Awan, A.G. \& Hashmi, S. (2014). Marketing practices of small \& medium size businesses: a case study of SME's in Multan District. European journal of business and innovation research, 2(6), 9-20.

Brassington, F. \& Pettitt, S. (2007). Essentials of marketing. 2nd edition. Harlow: Prentice Hall.

Batchelor, S.J. \& Web, M. (2002). E-commerce options for Third World craft producers: Final Technical Report. DFID Knowledge and Research Project R7792. [Accessed 15 November 2002]. http://www.vivabolivia.org/ development/economic/ecommerce_craft_producers.pdf. 
Brooksbank, G., Kirby D., Taylor, D. \& Jones-Evans, D. (1999). Marketing in medium-sized manufacturing firms: The state of the art in Britain, 1987-92. European Journal of Marketing, 33(1/2):103-120.

Braglia, M. \& Petroni, A. (2000). A quality assurance oriented methodology for handling trade-offs in supplier selection. International Journal of Physical Distribution \& Logistics Management, 30(2):96-111.

Blankson, C. \& Stokes D. (2002). Marketing practices in the UK small business sector. Marketing Intelligence \& Planning, 20(1):49-61.

Blueprint Strategy \& Policy. (2005). Promotion of Small and Medium Businesses in the South African Chemicals Sector. Support for SMEs in the South African Chemicals Sector. Prepared for Chemicals Summit NEDLAC.

Carter, S. \& Jones-Evans, D. (2000). Business and Small Business (Principles, practice and policy. New York: Pearson Education Limited.

Cassim, S. (2013). Communicating customer value: Integrating marketing communication strategies. In Kotler \& Armstrong: Global and Southern African perspectives, Principles of marketing. Cape Town: Pearson Prentice Hall.

Cape Craft \& Design Institute. (2008). 2010 FIFA Football World Cup South Africa: Identifying craft market access opportunities for Western Cape craft producers in the 2010 FIFA World Cup, South Africa and beyond. [Accessed 15 November 2013]. http://www.ccdi.org.za/research-and-publications/research/World\% 20Cup \%20market\%20opportunities\%20for\%20WC\%20craft\%20producers.pdf.

Cawley, M.E., Gaffey, S.M. \& Gilmor, D. A. (1999). The Role of Quality Tourism and Craft SMEs in Rural Development: Evidence from the Republic of Ireland, Anatolia,.10(1):45-60.

Clodfelter, R. 2008. Retail buying: from basics to fashion. $3^{\text {rd }}$ Edition, New York: Fairchild Books, INC,

Clow, K.E. \& Baack, D. (2004). Integrated advertising, promotion and marketing communications. 2nd edition. Upper Saddle River: Pearson Education.

Cooper, D.R. \& Schindler, P.S. (2006). Business Research Methods. $9^{\text {th }}$ Edition. New York, NY: McGraw-Hill.

Coviello, N. E., Brodie, R. J., \& Munro, H. J. (2000). An investigation of marketing practice by firm size. Journal of Business Venturing, 15, 523-545.

Cravens, D.W. \& Piercy, N.F. (2009). Strategic marketing. $9^{\text {th }}$ Ed. Singapore: McGraw-Hill International Edition.

Department of Labour. (2011). Labour market review: An investigation into the nature of employment relationships in the South African creative industry. [Accessed 15 November 2013]. http:/www.labour.gov.za/ DOL/downloads/ documents/research -documents/Creative\%20 Industries_DoL_Report.pdf.

Department of Labour. (2008). The creative industries in South Africa: Sector studies research project. [Accessed 15 November 2013]. http://www.labour.gov.za/DOL/ downloads/documents/ research-documents/ Creative\%20Industries_DoL_Report.pdf.

Department of Arts, Culture, Science and Technology. 1998. Cultural industries growth strategy (CIGS): The SA craft industry report. South Africa. November. [Accessed 15 November 2013]. www.gov.za/ documents / download.php?f=70487.

Department of Sports, Arts, Recreation and Culture. (2007). Final draft Gauteng craft strategy, October 2007.

Department of Trade \& Industry. (2005). Sector Development Strategy: Craft. South Africa. [Accessed 15 November 2013] http://www.ccdi.org.za/research-and-publications/research/Customised \%20Sector\%20 Programme\%20for\%20Craft.pdf.

Dhurup, M. \& Makhitha, K.M. (2014). Reflections on the constraints in entrepreneurial development among emerging survivalist and micro craft businesses in Gauteng. Journal of Contemporary Management, 11, 230-250.

Deeter-Schmelz, D.R. \& Kennedy, K.N. (2002). An exploratory study of the Internet as an individual communication tool: Examining buyer's perceptions. Industrial Marketing Management, 31:145-154.

Dwyer, F.R. \& Tanner, F. T. (2009). Business Marketing: Connecting strategy, relationships and learning. $4^{\text {th }}$ Ed. Boston:McGraw-Hill Irwin.

Ellis, P.D. (2005). Market orientation and marketing practice in a developing economy. European Journal of Marketing, 39(5/6):629-645.

Epstein, K. A. (2006). Marketing: made easy. Madison: Entrepreneur Press.

Field, A. \& Miles, J. (2010). Discovering statistics using SAS. London: Sage Publications.

Gilmore, A., Carson, D. \& Grant, K. (2001). SME marketing in practice. Marketing Intelligence \& Planning, 19(1):6-11.

Grobler, A.T. (2005). Product development for community-craft projects in Mpumalanga. An unpublished Masters dissertation, University of Pretoria.

Hair, J.F., Black, W.C., Babin, B.J. \& Anderson, R.E. (2010). Multivariate data analysis: A global perspective. $7^{\text {th }}$ Edition. New Jersey, USA: Pearson.

Hay, D. (2008). The business of craft and crafting the business: Strategies for success in the rural craft sector, 1-60. [Accessed 15 November 2014]. http://www.tcd.ufl.edu/Data/Sites/44/media/documents/tropilunch/2011/BusinesofCraftHandbooklowresolution.PDF.

Hilletofth, P. (2009). How to develop a differentiated supply chain strategy. Industrial Management and Data systems, 109(1):1633.

Hogarth-Scott S., Watson, K. \& Wilson, N. (1996). Do SMEs have to practice marketing to survive and grow. Marketing Intelligence \& Planning, 14(1):6-18. 
Hu, B. \& Yu, H. (2007). Segmentation by craft selection criteria and shopping involvement. Tourism Management, 20:10791092.

Kaiser \& Associates. (2005). Craft first paper. The Scope of the Craft Industry in the Western Cape. [Accessed 15 November 2013]. http://www.weterncape.gov.za/ other/2005/11/final_first_paper_craft.pdf.

Keller, K. L. (2009). Building strong brands in a modern marketing communications environment. Journal of Marketing Communications, 15(2-3), 139-155.

Ken, H. T., Nguyen, T. M. \& Ping, H. (2007). The effects of entrepreneurial orientation and marketing information on the performance of SMEs, Journal of Business Venturing, 22 (4): 592-611.

Kim, J.-O. \& Mueller, C. W. (1978). Factor analysis: Statistical methods and practical issues. Beverly Hills, CA: Sage Publications.

Khan, O. \& Creazza, A. (2009). Managing the product design-supply chain interface: Towards a roadmap to the "design centric business". International Journal of Physical Distribution \& Logistics Management, 39(4):301-319.

Lamb, C. W., Hair, J. F., McDaniel, C., Boshoff, C., Terblanche, N., Elliot, R., \& Klopper, H. B. (2011). Marketing. (4th ed.). Cape Town: Oxford University Press.

Lekhanya, L.M (2010). The Use of Marketing Strategies by Small, Medium and Micro Businesses in Rural KwaZulu-Natal. An unpublished PHD dissertation thesis, Durban University of Technology.

Littrell, M.A. \& Miller, N.J. (2001). Marketing across cultures. Journal of Global Marketing, 15(1):67-86.

Lotz, O. \& Marais, L. (2007). Manufacturing businesses and marketing planning in a mining area of the North West Province, South Africa: lessons for local business support centres. Development Southern Africa, 24(5), December.

Makhitha, KM. (2013). An investigation into the buyer behaviour of craft retailers in South Africa. An unpublished PHD thesis, University of Pretoria.

Makhitha, K.M., \& Bresler, N. (2011). The perceived marketing benefits of the 2010 FIFA World Cup for craft businesses. African Journal for Physical, Health Education, Recreation and Dance (Supplement),232-252.

Malhotra, N.K. (2010). Marketing research: An applied orientation. $6^{\text {th }}$ Edition. New York, NY: Pearson.

Mariotti, S. (2007). Entrepreneurship: Starting and operating a small business. Upper Saddle River, New Jersey: Pearson Education.

McCarthy, W. D., \& Perrealt, E. J. (1999). Basic marketing: A global-managerial. (13th ed.). Boston: McGraw-Hill.

McGrath,J.M. (2005). A Pilot Study Testing Aspects of IMC Concept. Journal of Marketing Communications, Vol.11 No.3, pp.1-20.

Moreno, J. \& Littrell, M.A. (2001). Negotiating Tradition: Tourism retailers in Guatemala. Annals of Tourism Research, 28(3):658-685.

Muhammed, M.Z., Char, A.K., Yasoa, M.R \& Hassan, Z. (2010). Small and Medium Businesses (SMEs) Competing in the Global Business Environment: A Case of Malaysia. International Business Research, 3(1), 66-75.

Nieman, G., Hough, J. \& Nieuwenhuizen, C. (2003). Entrepreneurship: A South Africa perspective. Pretoria: Van Schaik.

Obiri, M.N. (2002). Is market-led approach crucial to art and craft small and micro businesses growth and sustainability in the Kwazulu-Natal Midlands? An unpublished masters dissertation, University of Natal.

O’Dwyer, M., Gilmore, A. \& Carson, D. (2009). Innovative marketing in SMEs. European Journal of Marketing, 43,(1/2):46-61.

Osmonbekov, T., Bello, D.C. \& Gillilland, D.I. (2002). Adoption of electronic commerce tools in business procurement: enhanced buying centre structure and processes. Journal of Business and Industrial Marketing, 17(2/3):151-166.

Phillip, T.K. (2006). Business Development on the Margins: Making Markets work for the Poor. An unpublished PHD thesis, University of the Witwatersrand.

Pride, W. M., \& Ferrell, O. C. (2000). Marketing concepts and strategies. New York: Houghton Mifflin Company.

Radipere, S. \& Van Scheers, L. (2005). Investigating whether a lack of marketing and managerial skills is the main cause of business failure in South Africa. South African Journal of Economics and Management Sciences, 8 (4): 402.

Ranchhold. A. (2004). Marketing strategies: A twenty-first century approach. London: Pearson Education.

Reijonen, H. (2010). Do all SMEs practice same kind of marketing? Journal of Small Business and Business Development, 17(2):279-293.

Rogerson, C.M. (2010). The business of craft: Constraints and policy challenges in South Africa. Acta Academica, 42(3):115144.

Rogerson, C. M. (2000). The market development approach to SMME development: Implications for local government in South Africa. Urban Forum, 17 (1): 54-78.

Rogerson, C. M. (1999). SMME Infrastructure and policy in South Africa. [On line]. Available at:

http://196.4.93.10/compress/e-library/Infrastructure_Mandate_for_Change_1994-1999/Chapter_9.pdf.

Swanson, K.K. (2004). Tourists' and retailers' perceptions of souvenirs. Journal of Vacation Marketing, 1(4):363-377.

Sellschop, S., Goladblatt, W. \& Hemp, D. (2005). Craft South Africa. Pretoria: Pan Macmillan South Africa.

Simpson, M. \& Taylor, N. (2002). The role and relevance of marketing in SMEs: Towards a new model. Journal of Small Business and Business Development, 9(4):370-382.

Siu, W. (2000). Marketing and company performance of Chinese small firms in Hong Kong. Marketing Intelligence \& Planning, 18(5):292-307. 
Sternquist, B. \& Chen, Z. (2006). Food retail buyer behaviour in the People's Republic of China: a grounded theory model. Qualitative market Research: An International Journal. 9(3):243-265.

Stokes, D. \& Chen, H. (2009). Small business and the environment: Turning over a new leaf? Business Strategy Environment, 19 (5): 273-288.

Sudman, S. \& Blair, E. (1998). Marketing research: A problem solving approach. Boston: McGraw-Hill International Edition.

Tabachinik, B.G. \& Fidell, L.S. (2001). Using multivariate statistics. $4^{\text {th }}$ Edition, International student edition. Need Ham Heights, Mass: Pearson Education Company.

Torres, A.M. 2002 Marketing networks as a form of strategic alliance among craft businesses. International Journal of Non-profit and Voluntary Sector Marketing, 7(3):229-243.

Venter, P. \& Jansen Van Rensburg, M. (2009). Strategic marketing: theory and applications for competitive advantage. Oxford University Press.

Voortman, C. \& Makhitha, K.M. (2014). The alignment of product strategy to supply chain practices of craft businesses in Gauteng Province, South Africa. Journal of Transport and Supply Chain Management, 8(1), 1-11.

Wesgro. (2000). Wesgro background on the craft industry in the Western Cape. August. South Africa.

Walker, O. C., Mullins, J. W., \& Larréché. J. (2008). Marketing strategy: A decision focused approach. (6th ed.).Boston: McGraw-Hill International Edition.

Wesgro. (2000). Wesgro background on the craft industry in the Western Cape. August. South Africa.

USAID. (2006). Global market assessment for handicrafts. Vol. 1, Final Draft, July. [Accessed 15 November 2013]. http://pdf.usaid.gov/pdf_docs/PNADN210.pdf.

UNESCO. (1997). International Symposium on crafts and the international markets.

Urban-Econ Tourism. (2010). Feasibility Study for Umbumbulu Arts and Crafts Trade Centre. Quotation 38DED/2008. [Accessed 15 November 2013]. http://www.kznded.gov.za/Portals/0/24.01.10\%20Umbumbulu\%20Craft\%20Centre.pdf.

Van Scheers, L. (2011). SMEs' marketing skills challenges in South Africa. African Journal of Business management, 5(13), $5048-5056$.

Wesgro. (2000). Wesgro background on the craft industry in the Western Cape. August. South Africa.

Zikmund, W.G \& Babin, B.J. (2010). Exploring marketing research. $10^{\text {th }}$ Edition. USA:Thomson/South-Western.

Zimuto, J. (2013). The perception of small and medium businesses (SMEs) marketing managers on IMC strategy in Zimbabwe: a case of Masvingo urban. Journal of Arts, Science \& Commerce. 


\section{NOTES}

